\title{
Simulasi dan Analisis QoS Video Conference Melalui Jaringan Interworking IMS - UMTS Menggunakan Opnet
}

\author{
Dadiek Pranindito ${ }^{1}$, Petronella Pattinasarani ${ }^{2}$, Eko Fajar Cahyadi ${ }^{3}$ \\ 1,2,3 Program Studi S1 Teknik Telekomunikasi, ST3 Telkom Purwokerto \\ $1,2,3$ JL. D.I. Panjaitan 128 Purwokerto 53147 INDONESIA \\ Email korespondensi : dadiek@st3telkom.ac.id
}

Dikirim 02 Januari 2017, Direvisi 24 Januari 2017, Diterima 28 Februari 2017

\begin{abstract}
Abstrak - Next Generation Network (NGN) merupakan salah satu teknologi masa depan yang memberikan layanan berupa voice, data, multimedia, dan internet yang mengacu pada konvergensi layanan berbasis IP. Sebuah teknologi yang mendukung konsep konvergensi berbasis IP adalah IP Multimedia Subsystem (IMS). UMTS merupakan salah satu teknologi bergerak seluler generasi ke tiga $(3 \mathrm{G})$ yang sebagian besar masyarakat gunakan karena rata-rata masyarakat sudah menggunakan gadget yang mendukung jaringan $3 \mathrm{G}$. Dengan menggunakan jaringan 3G, masyarakat dapat melakukan komunikasi video conference. Video conference merupakan salah satu komunikasi jarak jauh yang bersifat real time sebagai pengganti tatap muka. Namun, layanan video conference pada jaringan IMS - UMTS perlu diketahui kelayakannya. Video conference merupakan layanan yang sensitif terhadap delay sehingga perlu dilakukan analisis QoS. Pada penelitian ini dilakukan simulasi dan analisis QoS video conference pada jaringan IMS - UMTS. Simulasi ini akan dibuat dengan menggunakan software OPNET modeler 14.5. Skenario yang digunakan adalah skenario Integrated Service (IntServ) untuk mengamati jaringan IMS dan Differentiated Service (DiffServ) untuk mengamati hubungan antara IMS dengan UMTS. Penelitian ini menggunakan jumlah user yang berbeda-beda yaitu 4 user, 8 user, dan 12 user dengan waktu simulasi yang berbeda, yaitu 100 detik, 200 detik, dan 300 detik. Dari hasil penelitian yang didapat, pada skenario Intserv dihasilkan nilai rata-rata terbesar untuk throughput adalah $26.643 \mathrm{Mbit} / \mathrm{s}$, end-to-end delay sebesar $233.069 \mathrm{~ms}$, dan jitter sebesar 0.073 ms. Untuk skenario Diffserv dihasilkan nilai rata-rata terbesar untuk throughput adalah $8.484 \mathrm{Mbit} / \mathrm{s}$, end-to-end delay sebesar $164.138 \mathrm{~ms}$, dan jitter sebesar $0.488 \mathrm{~ms}$. Untuk nilai packet loss ke dua skenario menghasilkan nilai kurang dari 1\%. Jika dilihat dari standar ITU-T G-114, rata-rata nilai parameter pada ke dua skenario termasuk dalam kategori baik.
\end{abstract}

Kata kunci - IMS, UMTS, IntServ, DiffServ, Video Conference.

Abstract - Next Generation Network (NGN) is one of the technologies of the future which services such as voice, data, multimedia, and internet which refers to the convergence of IP-based services. A technology that supports the concept of convergence based on IP is IP Multimedia Subsystem (IMS). UMTS is a third generation technology $(3 \mathrm{G})$ of mobile cellular that people use because people already using gadget which support $3 \mathrm{G}$. Using the $3 \mathrm{G}$ network, people can do video conferencing. Video conference is the one of comunication in a real time which replaces face-to-face. However, video conference on IMS - UMTS network need to know it is reasonable. Video conference has high sensitivity to delay, so should be analysis of QoS. This research will be conducted simulation and analysis QoS of video conference on IMS - UMTS network. This simulation will be created using OPNET modeler 14.5. The scenario in used is Integrated Service (IntServ) scenario for observed the value of Quality of Service (QoS) only on IMS network and Differentiated Services (DiffServ) scenario for observed the connection between IMS - UMTS network. This research used 4 user, 8 user, and 12 user. The time of running simulation is 100 second, 200 second, and 300 second. In the result of the research, in IntServ scenario, the highest value of throughput is $26.643 \mathrm{Mbit} / \mathrm{s}$, end-to-end delay is $233.069 \mathrm{~ms}$, and jitter is $0.073 \mathrm{~ms}$. In Diffserv scenario, the highest value of throughput is $8.484 \mathrm{Mbit} / \mathrm{s}$, end-to-end delay is $164.138 \mathrm{~ms}$, and jitter is $0.488 \mathrm{~ms}$. The result of packet loss for Intserv and Diffserv is under $1 \%$. All off them have a good quality because not exceed the standard ITU-T G114.

Keywords - IMS, UMTS, IntServ, DiffServ, Video Conference. 


\section{PENDAHULUAN}

IP Multimedia Subsystem (IMS) merupakan teknologi yang mengarah pada konvergensi antara jaringan wireless dan wireline. IMS digunakan untuk jaringan mobile dengan layanan berbasis IP. Layanan yang ditawarkan IMS juga beragam, tidak hanya voice namun juga dapat berupa data dan layanan multimedia lainnya. Salah satu layanan yang didukung teknologi IMS adalah video conference. Video conference merupakan layanan yang dapat memungkinkan dilakukannya komunikasi berupa data, suara, dan gambar secara duplex atau dua arah dan bersifat real time. Video conference banyak dilakukan saat ini untuk komunikasi jarak jauh seperti tatap muka langsung dengan menggunakan komputer atau laptop yang sudah memiliki webcam, bahkan saat ini video conference sudah dapat dilakukan di mana saja dan kapan saja dengan menggunakan smartphone [1].

Video conference sudah dapat dilakukan pada teknologi generasi ke tiga (3G). Universal Mobile Telecommunication Service (UMTS) merupakan salah satu teknologi yang temasuk dalam teknologi generasi ke tiga (3G). UMTS dapat memberikan kecepatan akses layanan data yang lebih tinggi dibanding teknologi sebelumnya dengan kecepatan akses yang dimiliki UMTS mencapai 384 kbps [2].

Quality of Service (QoS) merupakan pengukuran yang dilakukan untuk mengetahui kinerja dari suatu jaringan. Contoh teknik QoS adalah Integrated Service (IntServ) dan Differentiated Service (DiffServ). IntServ menyediakan aplikasi dengan tingkat jaminan layanan melalui negosiasi parameter jaringan secara end-to-end. Sedangkan DiffServ menyediakan suatu set perangkat klasifikasi dan mekanisme antrian terhadap protokol atau aplikasi dengan prioritas tertentu di atas jaringan yang berbeda [3].

Penelitian ini merupakan pengembangan dari penelitian yang sudah dilakukan sebelumnya oleh Khoem Sambath dengan judul "High Quality of Service Video Conferencing Over IMS". Pada penelitian tersebut dibahas perbandingan nilai QoS berupa delay, jitter, dan packet loss untuk layanan video conference pada jaringan antar IMS [3]. Sedangkan pada penelitian ini akan dilakukan penelitian terhadap jaringan interworking antara IMS dengan UMTS pada layanan video conference dan voice dengan parameter QoS berupa delay, jitter, packet loss, dan througput. Skenario yang digunakan dalam penelitian ini adalah Integrated Service (IntServ) dan Differentiated Service (DiffServ). Pada skenario IntServ akan diamati nilai Quality of Service (QoS) dari jaringan IMS, sedangkan pada skenario DiffServ akan diamati hubungan antara IMS dengan UMTS. Untuk ke dua skenario dilakukan penelitian dengan 3 keadaan waktu yaitu waktu simulasi 100 second, 200 second, dan 300 second dengan jumlah user yang berbeda-beda yaitu 4 user, 8 user, dan 12 user. Hasil simulasi yang didapat kemudian dibandingkan dengan standarisasi ITU-T.

Terdapat tiga jenis metode QoS yang sering digunakan, yaitu best-effort service, integrated service, dan differentiated service. Best-Effort Service digunakan untuk melakukan semua usaha agar dapat mengirimkan sebuah paket ke suatu tujuan. Metode ini tidak menjamin bahwa paket akan sampai ke tujuan yang dimaksud. IntServ menyediakan aplikasi dengan tingkat jaminan layanan melalui negosiasi parameter jaringan secara end-to-end. Sedangkan DiffServ menyediakan suatu set perangkat klasifikasi dan mekanisme antrian terhadap protokol atau aplikasi dengan prioritas tertentu di atas jaringan yang berbeda [3].

Parameter QoS yang digunakan untuk mengetahui kualitas dari suatu jaringan adalah delay, jitter, throughput, dan packet loss. Delay merupakan total waktu yang dibutuhkan suatu informasi atau data dari pengirim ke penerima pada suatu jaringan. Delay variation merupakan selang waktu kedatangan antar paket di tujuan. Throughput merupakan total kedatangan paket yang sukses sampai tujuan selama interval waktu tertentu dibagi oleh durasi interval waktu tersebut. Packet loss merupakan jumlah paket yang hilang saat proses pengiriman terjadi. Berikut merupakan nilai standarisasi kualitas layanan berdasarkan ITU-T G.114.

Tabel 1. Nilai Batasan Delay [4]

\begin{tabular}{clc}
\hline Delay $(\mathbf{m s})$ & \multicolumn{1}{c}{ Keterangan } & Kategori \\
\hline $0-150$ & $\begin{array}{l}\text { Dapat diterima } \\
\text { Dapat diterima, namun } \\
\text { administrator jaringan }\end{array}$ & Baik \\
harus waspada terhadap & Cukup \\
segala sesuatu yang & \\
dapat mempengaruhi & \\
& kualitas jaringan. & \\
& $\begin{array}{l}\text { Secara umum tidak } \\
\text { dapat diterima, namun }\end{array}$ & \\
untuk kasus-kasus & Buruk \\
& khusus nila batas ini & \\
dapat berubah & \\
\hline
\end{tabular}

Tabel 2. Nilai Batasan Jitter [4]

\begin{tabular}{clc}
\hline Jitter $(\mathbf{m s})$ & \multicolumn{1}{c}{ Keterangan } & Kategori \\
\hline $0-20$ & Dapat diterima & Baik \\
$20-50$ & Dapat diterima & Cukup \\
$>50$ & Tidak dapat diterima & Buruk \\
\hline
\end{tabular}

Tabel 3. Nilai Batasan Packet Loss [4]

\begin{tabular}{clc}
\hline $\begin{array}{c}\text { Packet Loss } \\
(\%)\end{array}$ & \multicolumn{1}{c}{ Keterangan } & Kategori \\
\hline $0-1$ & Dapat diterima & Baik \\
$1-5$ & Dapat diterima & Cukup \\
$>10$ & Tidak dapat diterima & Buruk \\
\hline
\end{tabular}




\section{METODE PENELITIAN}

\section{A. Parameter Penelitian}

Dalam penelitian ini dilakukan simulasi menggunakan skenario Integrated Service (IntServ) dan Differentiated Service (DiffServ). Layanan yang akan diamati adalah layanan video conference pada jaringan IMS dan interworking antara IMS dengan UMTS. Pada layanan tersebut akan diamati beberapa parameter yaitu delay, jitter, packet loss, dan throughput. Penelitian dilakukan dengan 3 keadaan waktu yaitu waktu simulasi 100 second, 200 second, dan 300 second dengan jumlah user yang berbeda-beda yaitu 4 user, 8 user, dan 12 user. Pada Tabel 4 ditunjukkan konsep pengambilan data yang digunakan pada penelitian ini.

Metode penelitian yang digunakan adalah metode eksperimen yaitu dengan melakukan simulasi terhadap jaringan IMS dan interworking IMS - UMTS dengan skenario Integrated Service (IntServ) dan Differentiated Service (DiffServ) menggunakan OPNET Modeler 14.5.

Tabel 4. Konsep Pengambilan Data

\begin{tabular}{|c|c|c|}
\hline Skenario & Intserv & Diffserv \\
\hline Parameter & $\begin{array}{c}\text { Throughput, End- } \\
\text { to-End Delay, } \\
\text { Jitter, dan Packet } \\
\text { Loss }\end{array}$ & $\begin{array}{c}\text { Throughput, End- } \\
\text { to-End Delay, } \\
\text { Jitter, dan Packet } \\
\text { Loss }\end{array}$ \\
\hline Jumlah User & $\begin{array}{c}4 \text { user, } 8 \text { user, dan } \\
12 \text { user }\end{array}$ & $\begin{array}{l}4 \text { user, } 8 \text { user } \\
\text { dan } 12 \text { user }\end{array}$ \\
\hline $\begin{array}{c}\text { Waktu } \\
\text { Simulasi }\end{array}$ & $\begin{array}{l}\text { 100, 200, dan } 300 \\
\text { second }\end{array}$ & $\begin{array}{c}100,200, \text { dan } 300 \\
\text { second }\end{array}$ \\
\hline
\end{tabular}

a) Skenario IntServ

Gambar 2 berikut merupakan topologi jaringan IMS pada OPNET Modeler 14.5 dengan menggunakan 8 user.

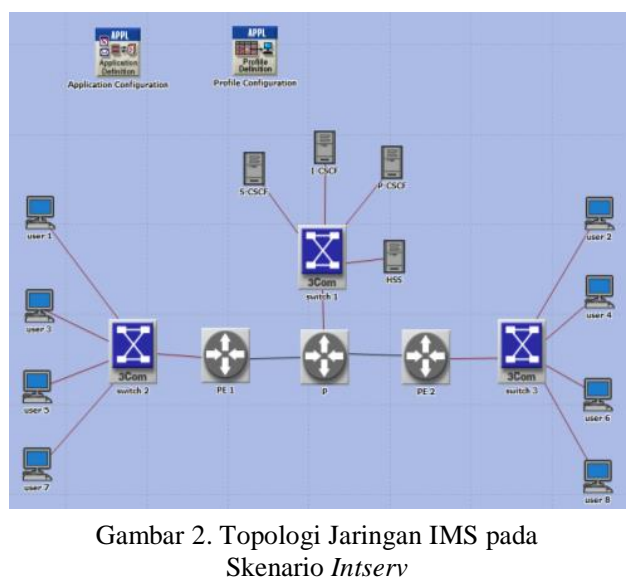

Konfigurasi dari perancangan topologi skenario Intserv adalah sebagai berikut.

\section{1) Application Configuration}

Komponen application digunakan untuk mendefinisikan layanan yang digunakan. Dalam penelitian ini, layanan yang digunakan adalah layanan video conference. Layanan video conference terbentuk dari layanan video dan voice, sehingga pada penelitian ini dibuat konfigurasi untuk video dan voice. Gambar 3 berikut merupakan tampilan dari application configuration dan akan dilakukan setting terkait dengan aplikasi yang akan digunakan. Dalam penelitian digunakan aplikasi video conference.

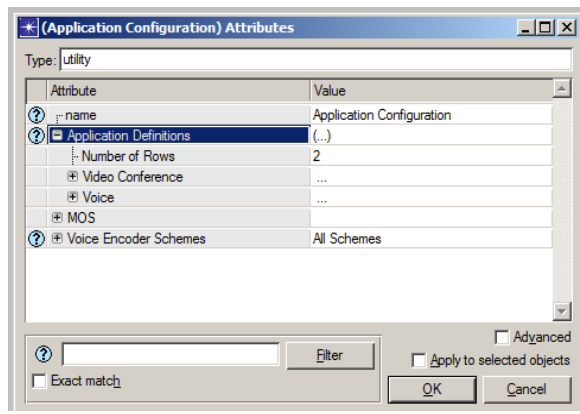

Gambar 3. Application Configuration

Gambar 4 ditunjukkan pengaturan untuk layanan video conference berdasarkan waktu di setiap frame-nya.

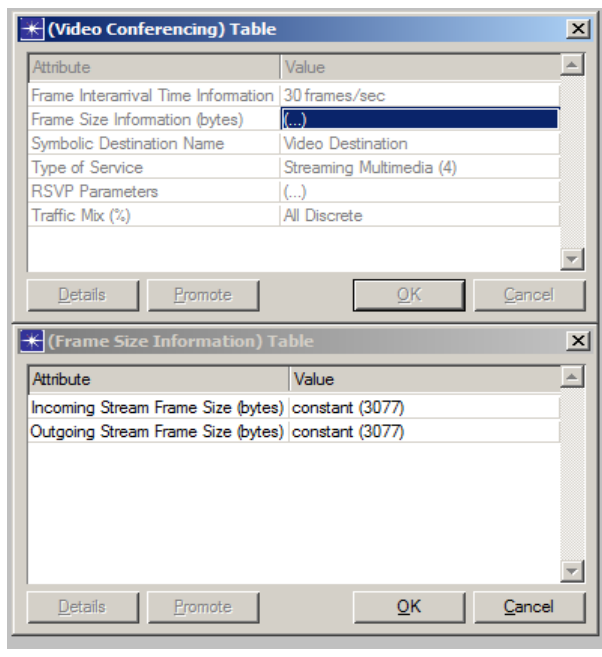

Gambar 4. Pengaturan Layanan Video Conference

Gambar 5 ditunjukkan pengaturan untuk layanan voice. Setting protokol yang digunakan untuk aplikasi video conference pada penelitian ini menggunakan protokol SIP.

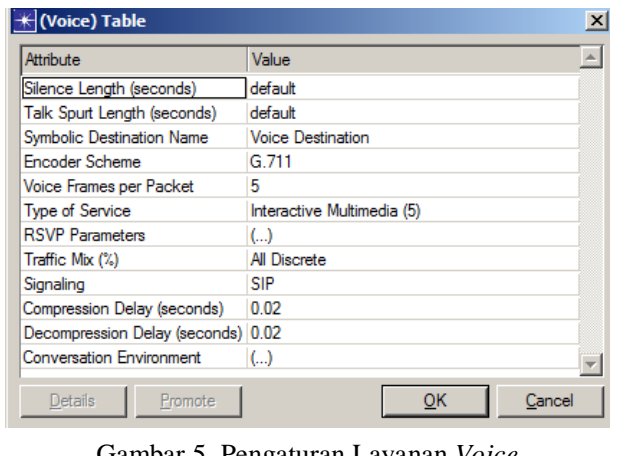

Gambar 5. Pengaturan Layanan Voice 
2) Profile Configuration

Komponen profile digunakan untuk mengkonfigurasi profil dari layanan yang digunakan yang telah didefinisikan pada komponen profile. Gambar 6 berikut merupakan tampilan dari profile configuration.

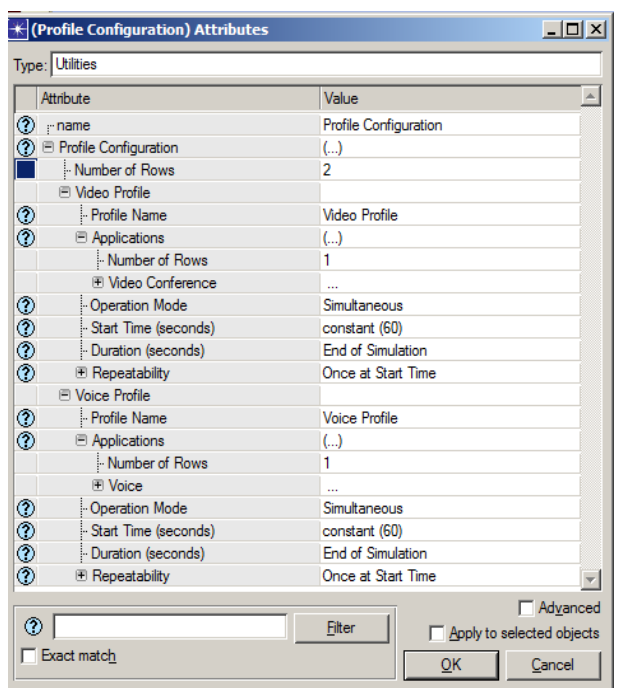

Gambar 6. Profile Configuration

3) Konfigurasi SIP Proxy Server

SIP proxy server merupakan komponen yang digunakan oleh jaringan SIP untuk melakukan pemrosesan panggilan antar perangkat SIP. SIP proxy server yang digunakan ada tiga jenis, yaitu ICSCF, S-CSCF, dan P-CSCF. Gambar 7, 8 dan 9 berikut merupakan tampilan dari pengaturan ICSCF, S-CSCF, dan P-CSCF.

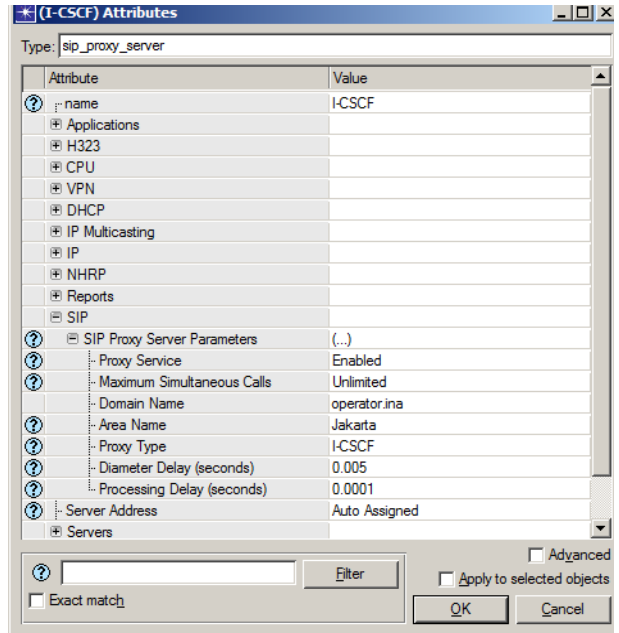

Gambar 7. Konfigurasi I-CSCF

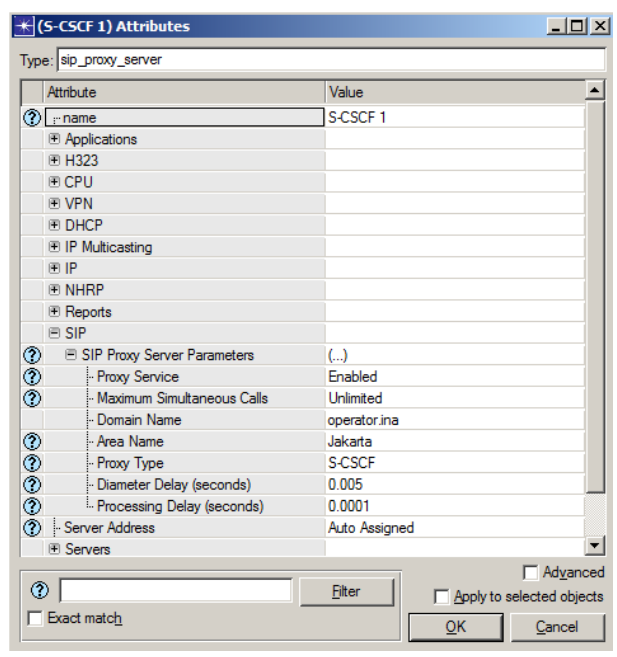

Gambar 8. Konfigurasi S-CSCF

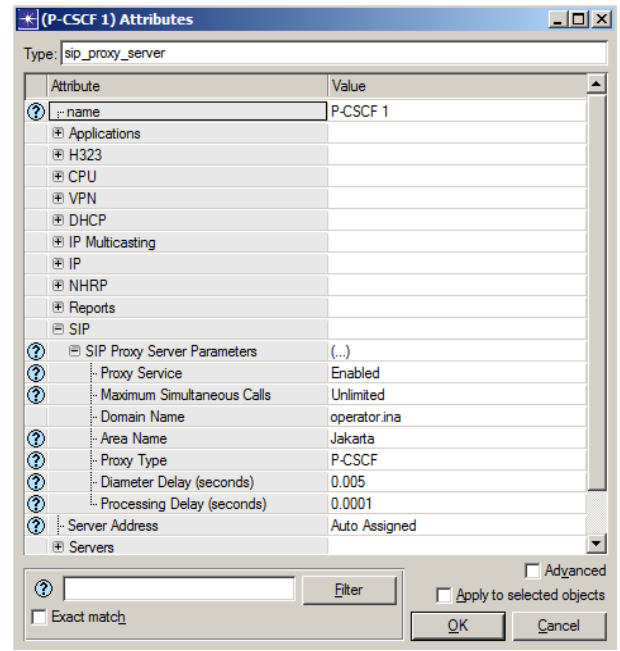

Gambar 9. Konfigurasi P-CSCF

4) Konfigurasi User

User yang digunakan pada penelitian ini adalah sebanyak 4 user, 8 user, dan 12 user. Gambar 10 berikut merupakan konfigurasi user untuk bagian application destination preference dan application supported profiles.

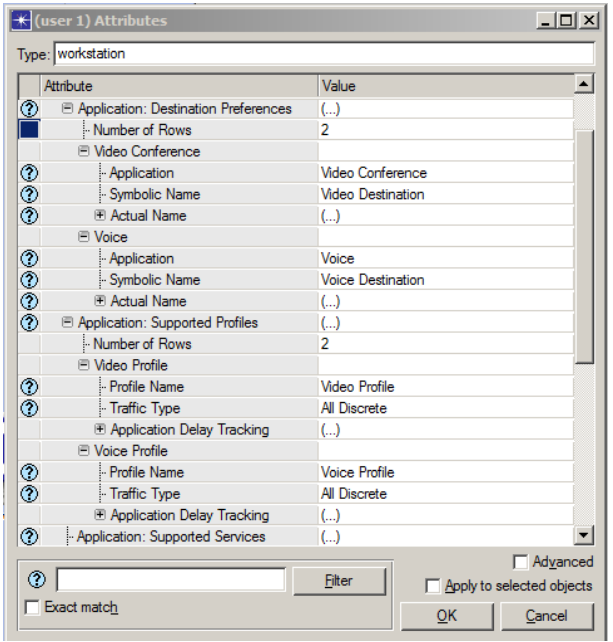

Gambar 10. Application Destination Preference dan Application Supported Profiles 
Gambar 11 berikut merupakan konfigurasi user untuk bagian application supported service.

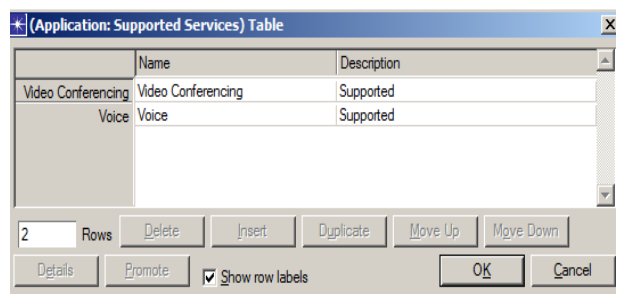

Gambar 11. Application Supported Service

Gambar 12 berikut merupakan konfigurasi user untuk bagian SIP UAC Parameters.

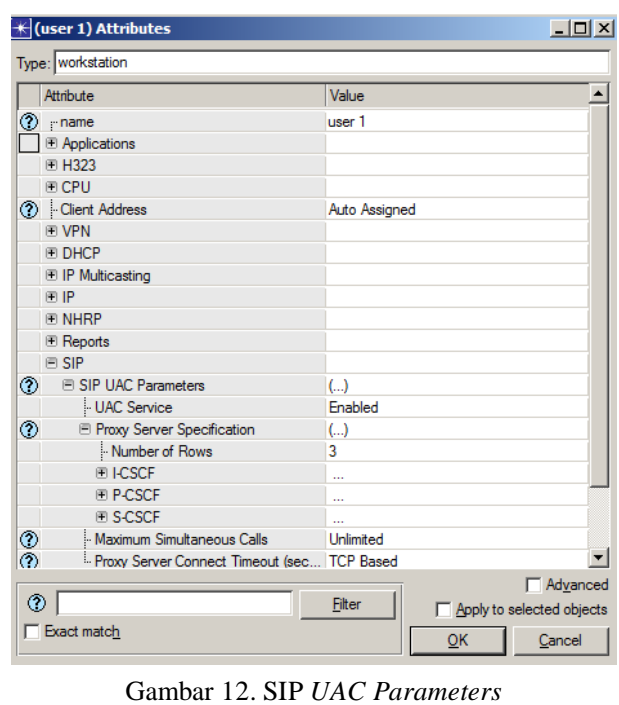

Konfigurasi user ini dilakukan juga pada skenario Diffserv untuk konfigurasi User Equipment (UE).

b) Skenario Diffserv

Pada skenario DiffServ akan dibuat sebuah topologi antara jaringan yang berbeda yaitu IMS dan UMTS. Pada Gambar 13 ditunjukkan topologi jaringan IMS dan UMTS pada OPNET Modeler 14.5 dengan menggunakan 8 user.

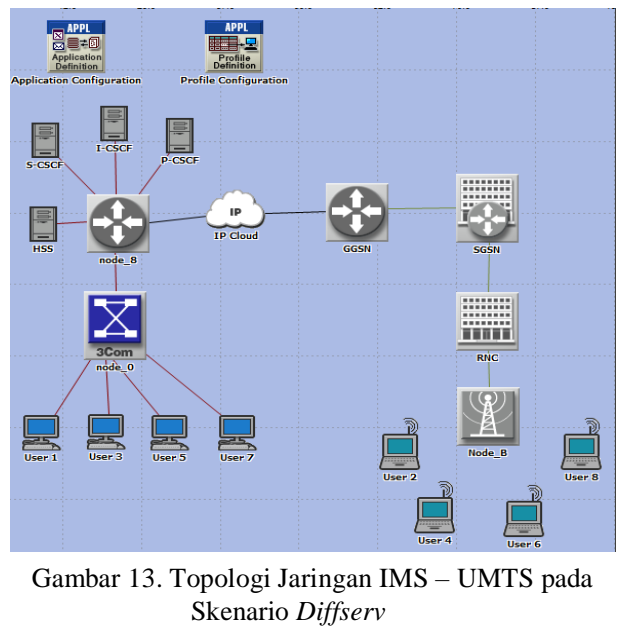

Pada skenario Diffserv, untuk konfigurasi Profile, beberapa komponen IMS seperti I-CSCF, S-CSCF, P-CSCF, dan user untuk IMS mengikuti langkah konfigurasi yang sudah dijelaskan sebelumnya yaitu pada konfigurasi skenario Intserv. Untuk komponen lain yang tidak ada pada skenario Intserv akan dijelaskan pada tahap konfigurasi berikut ini.

\section{1) Application Configuration}

Pada skenario diffserv, ToS diganti dengan menggunakan pilihan DSCP di mana digunakan kode untuk memprioritaskan layanan. Pada Gambar 14 ditunjukkan konfigurasi Application pada bagian ToS.

\begin{tabular}{|c|c|c|}
\hline \multicolumn{2}{|l|}{ *-(Voice) Table } & \\
\hline Attribute & Value & \\
\hline Silence Length (seconds) & default & \\
\hline Talk Spurt Length (seconds) & default & \\
\hline Symbolic Destination Name & Voice Destination & \\
\hline Encoder Scheme & G.711 & \\
\hline Voice Frames per Packet & 5 & \\
\hline Type of Service & EF & \\
\hline RSVP Parameters & None & \\
\hline Traffic Mix $(\%)$ & All Discrete & \\
\hline Signaling & None & \\
\hline Compression Delay (seconds) & 0.02 & \\
\hline Decompression Delay (seconds) & 0.02 & \\
\hline Conversation Environment & $(\ldots)$ & \\
\hline Promote & $\underline{\mathrm{Q} K}$ & Cancel \\
\hline
\end{tabular}

Gambar 14. Pengaturan Layanan pada Skenario Diffserv

Type of service pada skenario Diffserv untuk layanan video yaitu AF43 karena layanan yang digunakan adalah layanan video conference dimana layanan video conference diprioritaskan setelah layanan voice. Sedangkan voice menggunakan $\mathrm{EF}$ yang menandakan bahwa voice lebih diprioritaskan daripada layanan video.

\section{2) Konfigurasi GGSN}

GGSN merupakan perangkat UMTS yang digunakan sebagai gerbang paket data dengan jaringan luar. Gambar 15 berikut merupakan konfigurasi yang dilakukan pada komponen GGSN.

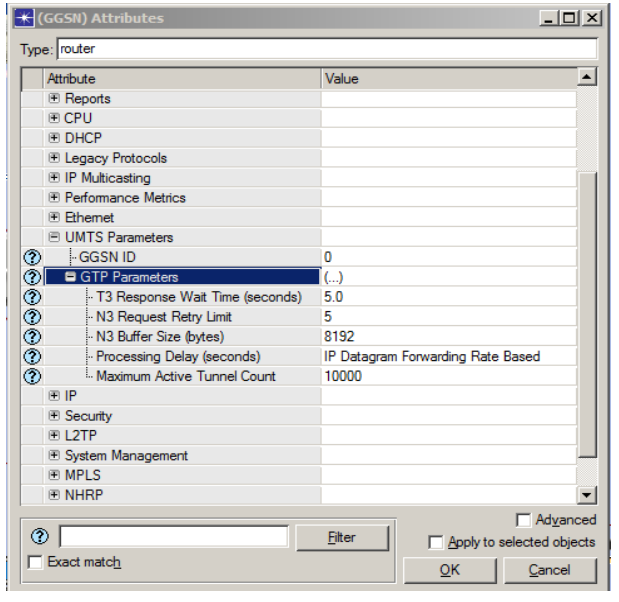

Gambar 15. Konfigurasi GGSN

3) Konfigurasi SGSN 
SGSN merupakan perangkat UMTS yang digunakan untuk mengirimkan paket dari dan ke UE. Gambar 16 berikut merupakan konfigurasi yang dilakukan pada komponen SGSN.

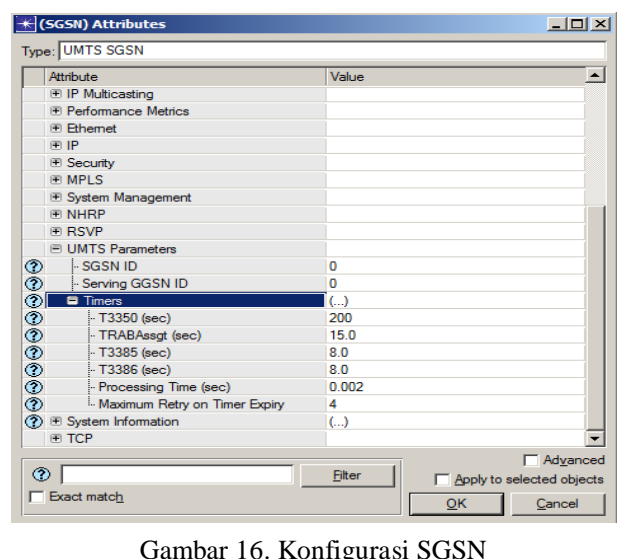

4) Konfigurasi RNC

RNC merupakan perangkat UMTS yang digunakan untuk mengontrol NodeB. Pada Gambar 17 ditunjukkan konfigurasi yang dilakukan pada komponen RNC.

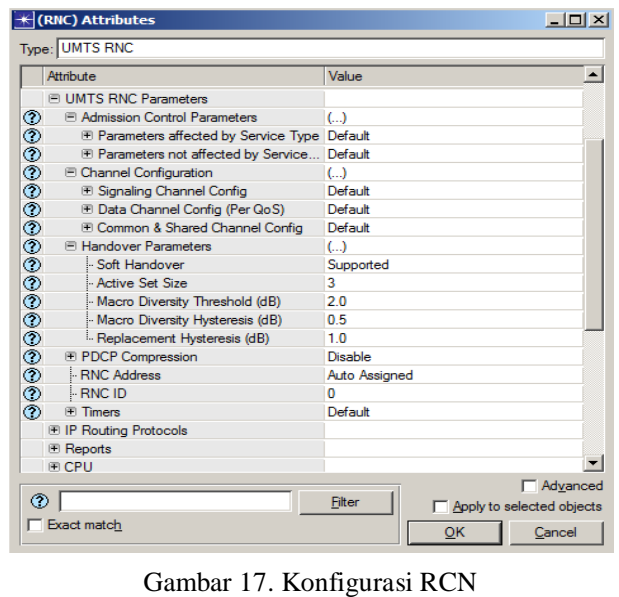

5) Konfigurasi NodeB

NodeB merupakan perangkat UMTS yang berperan sebagai BTS pada jaringan GSM. NodeB digunakan untuk mengirim dan menerima frekuensi. Pada Gambar 18 ditunjukkan konfigurasi yang dilakukan pada komponen NodeB.

\section{B. Metode Pengumpulan Data}

Proses pengumpulan data diperoleh dari hasil simulasi yang sudah dilakukan dan berhasil. Data yang diperoleh dari hasil simulasi adalah dalam bentuk grafik atau berupa nilai konversi dalam bentuk excel yang dihasilkan dari grafik tersebut.

\section{Analisa Hasil}

Analisa hasil dilakukan dengan menggunakan metode deskriptif yaitu dengan melakukan deskripsi atau penggambaran hasil dari beberapa parameter yang diamati yaitu delay, jitter, packet loss, dan throughput di mana hasil tersebut berupa grafik atau nilai konversi grafik. Kemudian dilakukan perbandingan antara hasil yang didapat tersebut dengan standarisasi ITU-T G. 114 apakah masih tergolong kategori baik atau tidak.

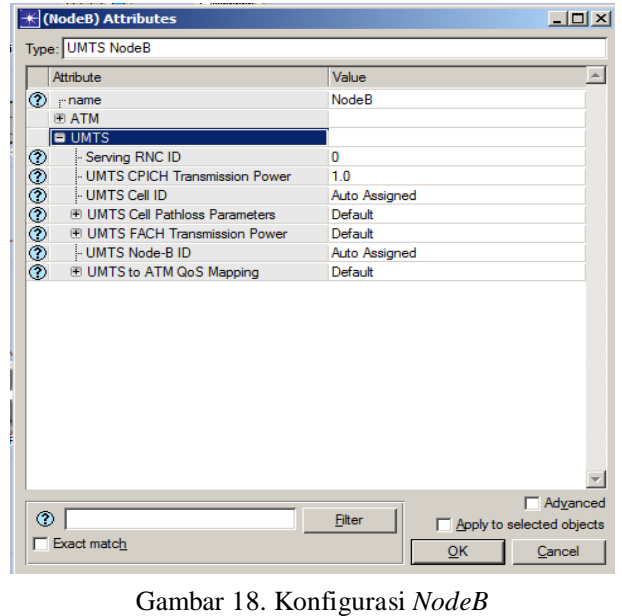

\section{HASIL DAN PEMBAHASAN}

Dari penelitian yang dilakukan dengan menggunakan 2 skenario, di mana pengambilan data dilakukan dalam waktu 100 second, 200 second, dan 300 second dengan jumlah user yang berbeda didapat hasil sebagai berikut.

A. Skenario Intserv

a) Throughput

Dari simulasi yang dilakukan didapatkan hasil nilai throughput untuk layanan video conference seperti yang ditunjukkan pada tabel 5 .

Tabel 5. Nilai Throughput pada Skenario Intserv

\begin{tabular}{cccc}
\hline \multirow{2}{*}{$\begin{array}{c}\text { Waktu } \\
\text { Simulasi }\end{array}$} & \multicolumn{3}{c}{ Throughput (Mbit/s) } \\
\cline { 2 - 4 } & $\mathbf{4}$ user & $\mathbf{8}$ user & 12 user \\
\hline $100 \mathrm{~s}$ & 0.862 & 1.381 & 1.881 \\
$200 \mathrm{~s}$ & 13.337 & 16.329 & 15.552 \\
$300 \mathrm{~s}$ & 26.331 & 27.246 & 26.353 \\
\hline
\end{tabular}

Dilihat dari Tabel 5 hasil throughput pada video conference untuk skenario Intserv, dapat dihitung nilai rata-rata per waktu simulasi yaitu pada waktu simulasi 100 second rata-rata throughput yang dihasilkan adalah $1.375 \mathrm{Mbit} / \mathrm{s}$, untuk waktu simulasi 200 second didapat nilai rata-rata sebesar 15.072 Mbit/s, dan untuk 300 second dihasilkan nilai rata-rata sebesar $26.643 \mathrm{Mbit} / \mathrm{s}$.

Pada penelitian ini, semakin lama waktu simulasi maka semakin besar pula nilai throughput yang dihasilkan. Hal tersebut dikarenakan semakin banyak paket yang dikirimkan dari pengirim ke penerima. Dari hasil simulasi, bila dilihat dari 8 user dan 12 user pada lama waktu 200 dan 300 second dapat dilihat bahwa semakin banyak user maka semakin kecil nilai throughput. Pada waktu simulasi 100 second dapat dilihat bahwa semakin banyak user maka throughput yang dihasilkan semakin besar. Hal ini dapat disebabkan dari 
jaringan yang belum stabil karena trafik pada penelitian ini dibangkitkan pada detik ke 70 sedangkan waktu simulai diambil selama 100 second. Pada Gambar 19 ditunjukkan grafik yang menggambarkan perubahan nilai throughput pada layanan video conference.

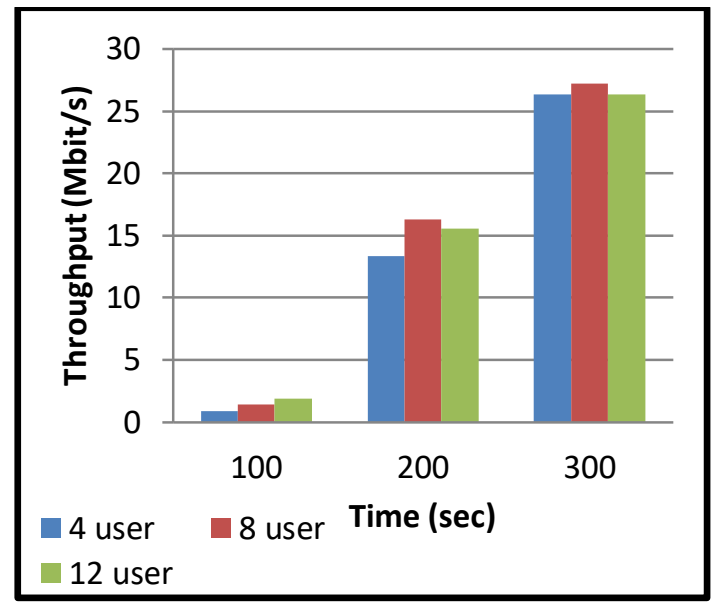

Gambar 19. Grafik Throughput pada Skenario Intserv

b) End-to-End Delay

End-to-End Delay merupakan waktu yang dibutuhkan suatu informasi atau data dari pengirim sampai ke penerima. Dari pengambilan data selama 100, 200, dan 300 second dengan jumlah user yang berbeda dihasilkan nilai End-to-End Delay pada video conference seperti yang ditunjukkan pada Tabel 6.

\begin{tabular}{cccc} 
Tabel 6. Nilai End-to-End Delay pada Skenario Intserv \\
\hline Waktu & \multicolumn{3}{c}{ Rata-Rata Delay $(\mathbf{m s})$} \\
\cline { 2 - 4 } Simulasi & $\mathbf{4}$ User & 8 User & $\mathbf{1 2}$ User \\
\hline $100 \mathrm{~s}$ & 143.183 & 144.176 & 146.418 \\
$200 \mathrm{~s}$ & 152.609 & 209.999 & 226.475 \\
$300 \mathrm{~s}$ & 186.944 & 264.089 & 248.174 \\
\hline
\end{tabular}

End-to-End Delay pada video conference untuk lama simulasi 100 second dengan penggunaan user yang berbeda jumlahnya didapatkan hasil yang masih memenuhi standar dan termasuk dalam kategori baik karena nilai yang dihasilkan kurang dari $150 \mathrm{~ms}$. Rata-rata untuk simulasi 100 second adalah $144.593 \mathrm{~ms}$. Untuk lama simulasi 200 second, nilai yang dihasilkan sudah lebih dari 150 ms sehingga termasuk dalam kategori cukup yaitu antara 150 sampai dengan $400 \mathrm{~ms}$. Rata-rata untuk simulasi 200 second adalah $196.361 \mathrm{~ms}$. Begitu juga untuk lama simulasi 300 second, tiap kelompok user didapat nilai rata-rata lebih dari 150 ms tetapi tidak lebih dari $400 \mathrm{~ms}$ sehingga termasuk dalam kategori cukup dan masih dapat diterima. Rata-rata untuk simulasi 300 second adalah 233.069 ms. Dari hasil tersebut maka dapat dikatakan bahwa proses komunikasi untuk layanan video conference pada jaringan IMS masih dapat berjalan dengan baik.
Pada penelitian ini, untuk layanan video conference dari lama waktu simulasi 100 second, 200 second, dan 300 second dengan jumlah user yang berbeda-beda mengalami kenaikan nilai endto-end delay. Semakin lama waktu simulasi, maka semakin besar nilai end-to-end delay yang dihasilkan. Semakin besar nilai delay yang dihasilkan, akan menyebabkan throughput yang dihasilkan semakin kecil. Hal tersebut dapat terlihat pada waktu simulasi 300 second dengan menggunakan 8 user dan 12 user, di mana delay pada 12 user lebih besar dari 8 user sehingga throughput pada 12 user lebih kecil daripada saat menggunakan 8 user. Pada Gambar 20 ditunjukkan grafik perubahan yang dapat menggambarkan nilai end-to-end delay untuk layanan video conference.

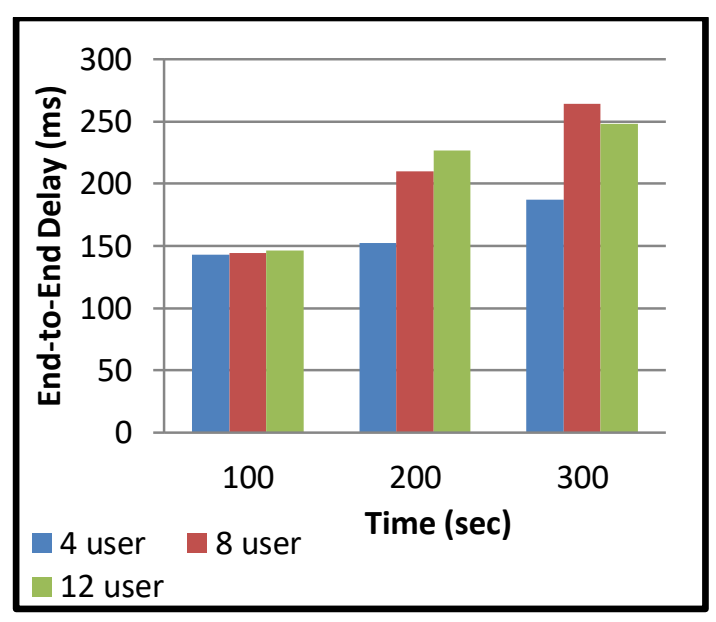

Gambar 20. Grafik End-to-End Delay pada Skenario Intserv

c) Jitter

Dari pengambilan data simulasi yang dilakukan selama 100, 200, dan 300 second serta dari jumlah user yang digunakan dihasilkan nilai rata-rata jitter yang merupakan variasi delay yang terjadi antar paket seperti yang ditunjukkan pada Tabel 7 .

Tabel 7. Nilai Jitter pada Skenario Intserv

\begin{tabular}{cccc}
\hline Waktu & \multicolumn{3}{c}{ Rata-Rata Jitter $(\mathrm{ms})$} \\
\cline { 2 - 4 } Simulasi & 4 User & 8 User & 12 User \\
\hline $100 \mathrm{~s}$ & 0.00208 & 0.00106 & 0.00325 \\
$200 \mathrm{~s}$ & 0.01705 & 0.08932 & 0.10395 \\
$300 \mathrm{~s}$ & 0.03449 & 0.09421 & 0.08887 \\
\hline
\end{tabular}

Nilai jitter dari hasil yang didapatkan untuk waktu simulasi 100 second, 200 second, dan 300 second dengan menggunakan 4 user, 8 user, dan 12 user termasuk dalam kategori baik di mana nilai jitter yang masih kurang dari $20 \mathrm{~ms}$ adalah termasuk dalam kategori baik. Dari hasil tersebut maka dapat dikatakan bahwa proses komunikasi untuk layanan video conference pada jaringan IMS masih dapat berjalan dengan baik saat menggunakan 12 user karena nilai jitter yang dihasilkan termasuk dalam kategori baik. 
Jitter terjadi akibat adanya selisih waktu kedatangan antar paket di penerima. Semakin besar nilai jitter maka semakin besar pula nilai delay yang dihasilkan. Proses komunikasi akan semakin baik jika nilai jitter yang dihasilkan kecil. Pada Gambar 21 ditunjukkan grafik yang menggambarkan perubahan nilai jitter pada skenario Intserv.

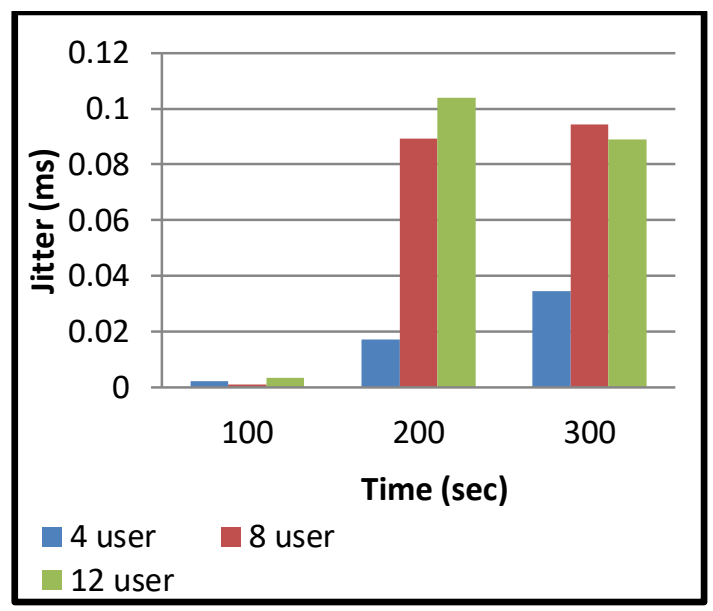

Gambar 21. Grafik Jitter untuk Skenario Intserv

\section{d) Packet Loss}

Packet loss merupakan paket yang hilang pada saat proses pengiriman hingga sampai ke penerima. Pada simulasi yang dilakuan dihasilkan nilai packet loss pada video conference seperti yang ditunjukkan pada Tabel 8.

Tabel 8. Nilai Packet Loss pada Skenario Intserv

\begin{tabular}{cccc}
\hline \multirow{2}{*}{$\begin{array}{c}\text { Waktu } \\
\text { Simulasi }\end{array}$} & \multicolumn{3}{c}{ Rata-Rata Packet Loss (\%) } \\
\cline { 2 - 4 } & 4 User & 8 User & 12 User \\
\hline $100 \mathrm{~s}$ & 0.001375 & 0.001493 & 0.001378 \\
$200 \mathrm{~s}$ & 0.035345 & 0.216268 & 0.371707 \\
$300 \mathrm{~s}$ & 0.177672 & 0.389544 & 0.472989 \\
\hline
\end{tabular}

Nilai packet loss dari hasil yang didapatkan untuk waktu simulasi 100 second, 200 second, dan 300 second dengan menggunakan 4 user, 8 user, dan 12 user termasuk dalam kategori baik yaitu mengacu pada Tabel 8 di mana nilai packet loss yang masih kurang dari $1 \%$ adalah termasuk dalam kategori baik. Dari hasil tersebut maka dapat dikatakan bahwa proses komunikasi untuk layanan video conference pada jaringan IMS masih dapat berjalan dengan baik saat menggunakan 12 user karena nilai packet loss adalah kurang dari $1 \%$ sehingga tidak banyak data yang hilang.

Pada Gambar 22 ditunjukkan grafik yang menggambarkan perubahan nilai packet loss pada layanan video conference.

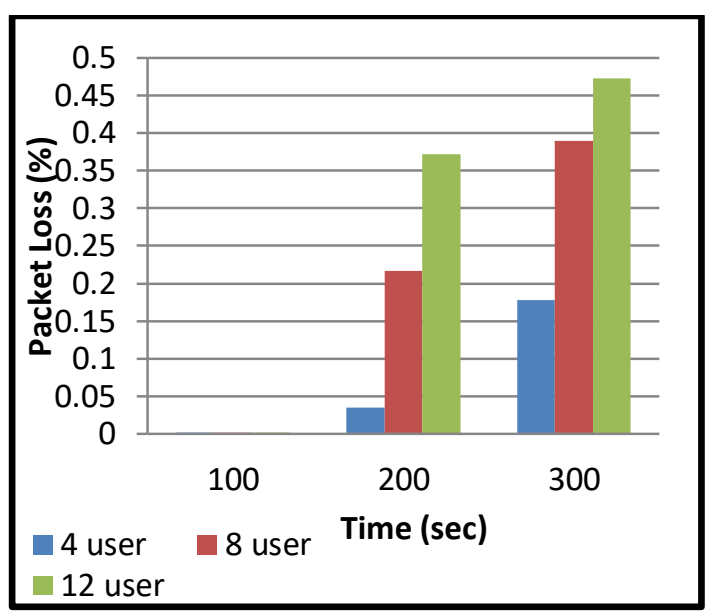

Gambar 22. Grafik Packet Loss pada Skenario Intserv

Pada Gambar 22 untuk lama waktu 100 second didapatkan nilai packet loss yaitu sebesar $0.001375 \%$ saat menggunakan 4 user,sebesar $0.001493 \%$ saat menggunakan 8 user, dan sebesar $0.001378 \%$ saat menggunakan 12 user. Jika dibandingkan dengan waktu simulasi 200 second dan 300 second pada gambar terlihat perbedaan yang signifikan.

\section{B. Skenario Diffserv}

\section{a) Throughput}

Nilai throughput untuk layanan video conference pada skenario Diffserv seperti yang ditunjukkan pada Tabel 9.

Tabel 9. Nilai Throughput pada Skenario Diffserv

\begin{tabular}{cccc}
\hline \multirow{2}{*}{$\begin{array}{c}\text { Waktu } \\
\text { Simulasi }\end{array}$} & \multicolumn{3}{c}{ Rata-Rata Throughput } \\
\cline { 2 - 4 } & $\mathbf{4}$ user & $\mathbf{8}$ user & $\mathbf{1 2}$ user \\
\hline $100 \mathrm{~s}$ & 0.283 & 0.239 & 0.222 \\
$200 \mathrm{~s}$ & 3.484 & 3.379 & 3.569 \\
$300 \mathrm{~s}$ & 8.767 & 8.249 & 8.436 \\
\hline
\end{tabular}

Jika dilihat dari tabel hasil nilai throughput untuk skenario Diffserv, dapat dihitung nilai ratarata per waktu simulasi yaitu pada waktu simulasi 100 second rata-rata throughput yang dihasilkan adalah 0.248 Mbit/s, untuk waktu simulasi 200 second didapat nilai rata-rata sebesar $3.477 \mathrm{Mbit} / \mathrm{s}$, dan untuk 300 second dihasilkan nilai rata-rata sebesar $8.484 \mathrm{Mbit} / \mathrm{s}$.

Dari nilai Throughput yang dihasilkan, semakin lama waktu simulasi maka semakin besar pula nilai throughput. Hal tersebut dikarenakan semakin banyak paket yang dikirimkan dari pengirim ke penerima. Dari hasil simulasi, bila dilihat dari 8 user dan 12 user dapat dilihat bahwa semakin banyak user maka semakin kecil nilai throughput. Pada Gambar 23 ditunjukkan grafik yang menggambarkan perubahan nilai throughput pada skenario Diffserv. 


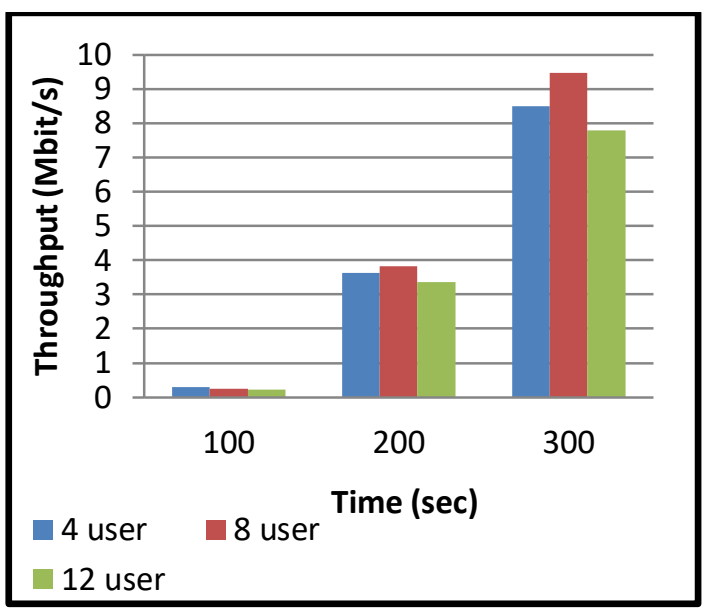

Gambar 23. Grafik Throughput pada Skenario Diffserv

b) End-to-End Delay

End-to-End delay pada video conference didapat hasil seperti yang ditunjukkan Tabel 10.

Tabel 10. Nilai End-to-End Delay pada Skenario Diffserv

\begin{tabular}{cccc}
\hline \multirow{2}{*}{$\begin{array}{c}\text { Waktu } \\
\text { Simulasi }\end{array}$} & \multicolumn{3}{c}{ Rata-Rata Delay (ms) } \\
\cline { 2 - 4 } & 4 User & 8 User & 12 User \\
\hline $100 \mathrm{~s}$ & 94.050 & 140.632 & 140.721 \\
$200 \mathrm{~s}$ & 162.711 & 148.676 & 150.160 \\
$300 \mathrm{~s}$ & 173.864 & 156.371 & 162.179 \\
\hline
\end{tabular}

End-to-End Delay pada skenario Diffserv untuk lama simulasi 100 second dengan penggunaan 4 user, 8 user, dan 12 user didapatkan hasil yang masih memenuhi standar dan termasuk dalam kategori baik karena nilai yang dihasilkan kurang dari $150 \mathrm{~ms}$. Rata-rata untuk simulasi 100 second adalah $125.134 \mathrm{~ms}$. Untuk lama simulasi 200 second, rata-rata yang didapatkan adalah 153.849 $\mathrm{ms}$. Karena nilai yang dihasilkan lebih dari $150 \mathrm{~ms}$ maka termasuk dalam kategori cukup dan masih dapat diterima. Untuk lama simulasi 300 second menghasilkan nilai lebih dari $150 \mathrm{~ms}$ tetapi kurang dari $400 \mathrm{~ms}$ sehingga termasuk dalam kategori cukup dan dapat diterima. Rata-rata untuk simulasi 300 second adalah $164.138 \mathrm{~ms}$.

Dari hasil tersebut maka dapat dikatakan bahwa proses komunikasi untuk layanan video conference pada jaringan IMS - UMTS dapat berjalan dengan kualitas yang baik karena nilai end-to-end delay yang dihasilkan masih dapat diterima. Pada Gambar 24 ditunjukkan grafik yang menggambarkan nilai end-to-end delay untuk layanan video conference pada skenario Diffserv.

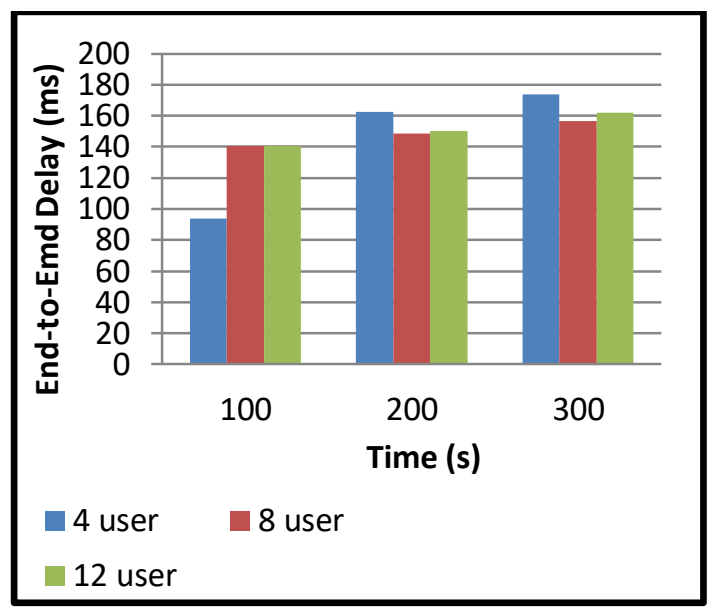

Gambar 24. Grafik End-to-End Delay pada Skenario Diffserv

c) Jitter

Nilai jitter pada video conference untuk skenario Diffserv seperti yang ditunjukkan pada Tabel 11.

Tabel 11. Nilai Jitter pada Skenario Diffserv

\begin{tabular}{cccc}
\hline \multirow{2}{*}{$\begin{array}{c}\text { Waktu } \\
\text { Simulasi }\end{array}$} & \multicolumn{3}{c}{ Rata-Rata Jitter $(\mathbf{m s})$} \\
\cline { 2 - 4 } & 4 User & 8 User & 12 User \\
\hline $100 \mathrm{~s}$ & 0.0000089 & 0 & 0.0000018 \\
$200 \mathrm{~s}$ & 1.069 & 0.300 & 0.095 \\
$300 \mathrm{~s}$ & 0.888 & 0.295 & 0.099 \\
\hline
\end{tabular}

Nilai jitter dari hasil yang didapatkan untuk waktu simulasi 100 second, 200 second, dan 300 second dengan menggunakan 4 user, 8 user, dan 12 user termasuk dalam kategori baik karena nilai yang dihasilkan tidak lebih dari $20 \mathrm{~ms}$. Dari hasil tersebut maka dapat dikatakan bahwa proses komunikasi untuk layanan video conference pada jaringan IMS - UMTS dapat berjalan dengan baik karena nilai jitter yang dihasilkan dapat diterima bahkan termasuk dalam kategori baik. Pada Gambar 25 ditunjukkan grafik yang menggambarkan perubahan nilai jitter pada skenario Diffserv.

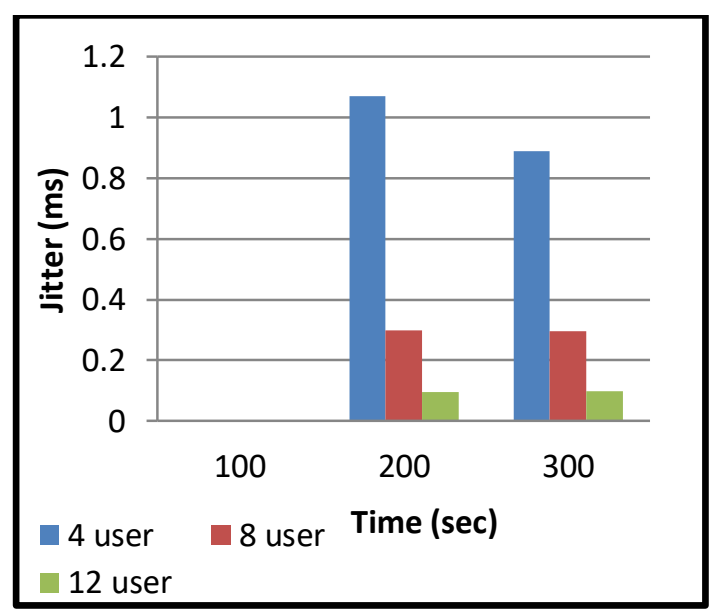

Gambar 25. Grafik Jitter pada Skenario Diffserv 
Dari Gambar 25 di atas, nilai yang didapat pada lama simulasi 100 second saat menggunakan 4 user didapat nilai sebesar $0.0000089 \mathrm{~ms}$, menggunakan 8 user adalah sebesar $0 \mathrm{~ms}$, dan saat menggunakan 12 user adalah sebesar 0.0000018 ms. Jika dibandingkan dengan lama waktu simulasi 200 second dan 300 second sangat terlihat perbedaan yang signifikan seperti yang dilihat pada grafik. Perbedaan nilai tersebut terjadi karena perbedaan besarnya paket data pada saat simulasi 200 second dan 300 second

\section{d) Packet Loss}

Untuk packet loss untuk video conference pada skenario Diffserv didapat hasil seperti yang ditunjukkan pada Tabel 12 .

Tabel 12. Nilai Packet Loss pada Skenario Diffserv

\begin{tabular}{cccc}
\hline \multirow{2}{*}{$\begin{array}{c}\text { Waktu } \\
\text { Simulasi }\end{array}$} & \multicolumn{3}{c}{ Rata-Rata Packet Loss (\%) } \\
\cline { 2 - 4 } & 4 User & 8 User & 12 User \\
\hline $100 \mathrm{~s}$ & 0.0012 & 0.0009 & 0.0007 \\
$200 \mathrm{~s}$ & 0.1842 & 0.2017 & 0.2044 \\
$300 \mathrm{~s}$ & 0.1852 & 0.2405 & 0.2351 \\
\hline
\end{tabular}

Nilai packet loss dari hasil yang didapatkan untuk waktu simulasi 100 second, 200 second, dan 300 second dengan menggunakan 4 user, 8 user, dan 12 user termasuk dalam kategori baik di mana nilai packet loss yang masih kurang dari $1 \%$ termasuk dalam kategori baik. Dari tabel tersebut setiap usernya memiliki perbedaan nilai yang tidak terlalu signifikan. Perbedaan nilai tersebut tidak dipengaruhi oleh banyaknya user melainkan lebih terlihat perbedaannya saat terjadi penambahan waktu simulasi. Hasil tersebut menunjukkan bahwa proses komunikasi untuk layanan video conference pada jaringan IMS - UMTS dapat berjalan dengan baik karena nilai packet loss yang dihasilkan kurang dari $1 \%$ sehingga tidak banyak data yang hilang.

Pada Gambar 26 ditunjukkan grafik yang menggambarkan perubahan nilai packet loss untuk layanan video conference pada skenario Diffserv.

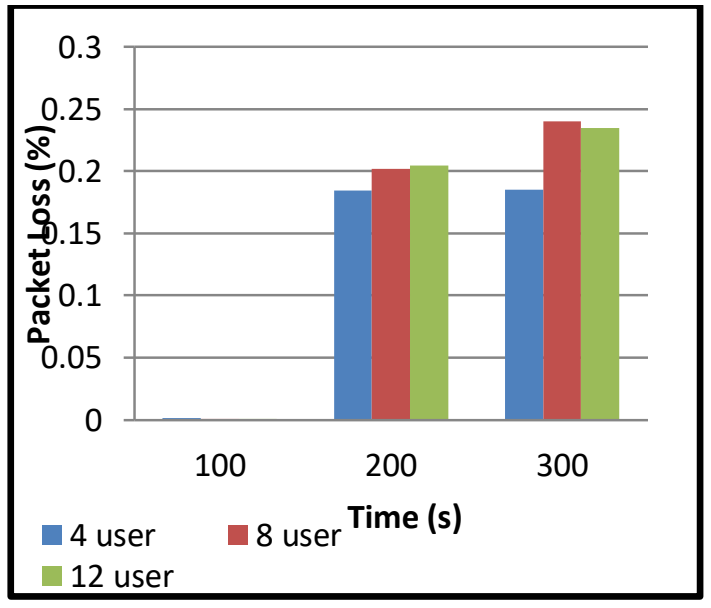

Gambar 26. Grafik Packet Loss pada Skenario Diffserv
Pada Gambar 26 untuk lama waktu 100 second didapatkan nilai packet loss yaitu sebesar $0.0012 \%$ saat menggunakan 4 user, sebesar $0.0009 \%$ saat menggunakan 8 user, dan sebesar $0.0007 \%$ saat menggunakan 12 user. Jika dibandingkan dengan waktu simulasi 200 second dan 300 second pada gambar terlihat hasil yang signifikan.

\section{PENUTUP}

\section{A. Kesimpulan}

Hasil Simulasi skenario Intserv dan Diffserv pada penelitian ini dapat berjalan dengan baik. Hal ini ditunjukkan dengan kelayakan jaringan IMS - IMS dan jaringan IMS - UMTS yang ditandai dengan didapatkannya nilai parameter QoS yang sesuai dengan standar ITU-T G.114. Sehingga proses komunikasi dengan menggunakan layanan video conference pada jaringan tersebut dapat berjalan dengan baik.

Pada skenario Intserv didapatkan nilai rata-rata terbesar untuk masing-masing parameter, yaitu untuk throughput sebesar $26.643 \mathrm{Mbit} / \mathrm{s}$, end-to-end delay sebesar $233.069 \mathrm{~ms}$, dan jitter sebesar $0.073 \mathrm{~ms}$. Nilai packet loss pada skenario Intserv adalah kurang dari 1 $\%$.

Pada skenario Diffserv didapatkan nilai rata-rata terbesar untuk masing-masing parameter, yaitu untuk throughput sebesar $8.484 \mathrm{Mbit} / \mathrm{s}$, end-to-end delay sebesar $164.138 \mathrm{~ms}$, dan jitter sebesar $0.488 \mathrm{~ms}$ dengan nilai packet loss yang didapat kurang dari $1 \%$.

\section{B. Saran}

Penelitian selanjutnya dapat menggunakan interworking dengan teknologi yang lain, seperti : IMS - 4G/LTE, IMS - WIMAX. Untuk memberikan hasil analisa yang lebih baik dapat dilakukan dengan menggunakan Type of Service (ToS) atau DSCP yang berbeda.

\section{DAFTAR PUSTAKA}

[1] Rebecca Copeland, Converging NGN Wireline and Mobile 3G Network with IMS, Taylor \& Francis Group, U.S.A, 2009

[2] L.Wardhana, Alfin Hikmaturokhman, $4 G$ Handbook Edisi Bahasa Indonesia, Jilid 1. https://www.academia.edu/8744637/4G_Handb ook_Versi_Bahasa_Indonesia, 2014.

[3] C. W. Hermawan, Kupas Tuntas Teknologi WIMAX. Semarang: Wahana Komputer, 2009.

[4] D. C. Nurdiansyah, "Implementasi Video Conference Pada Jaringan HSUPA ( High Speed Uplink Packet Acces ) Dengan Media IPv6 Menggunakan Simulator," pp. 4-9, 2013.

[5] K. Sambath, M. Abdurahman, and V. Suryani, "High Quality of Service Video Conferencing over IMS," no. June, pp. 470-476, 2016.

[6] R. D. Cahyani, A. Hikmaturokhman, and E. F. Cahyadi, "Analisa Karakteristik Teori Antrian pada Jaringan IP Multimedia, 2015. 
[7] A. Wardita and I. Santoso, "Perbandingan Kinerja AM (Acknowledged Mode) Dan UM (Unacknowledged Mode) Sub-Layer RLC (Radio Link Control) Jaringan UMTS pada Trafik Layanan Aplikasi Menggunakan OPNET" Transient, vol. Vol. 2, 2013.

[8] N. E. Fitriani, A. Hikmaturokhman, and E. F. Cahyadi, "Analisa Karakteristik Teori Antrian Pada Jaringan Universal Mobile
Telecommunication System ( UMTS )," pp. 1-13, 2015.

[9] One-Way Transmission Time. ITU-T Recommendation G.114, (Mei, 2003).

[10] Hadi, S,Z, Muhammad. Pengukuran QoS (Quality of Service) Pada Streaming Server. Modul Jarkom 2. Institut Teknologi Surabaya, 2016. 